\title{
Tattua
}

JOURNAL OF PHILOSOPHY

\section{EDUCATIONAL PHILOSOPHIES OF THOMAS AQUINAS AND ALFRED NORTH WHITEHEAD: BEACONS FOR THE MODERN EDUCATOR}

\author{
Dr. Joseph Murik \\ University of Canberra, Australia
}

\section{Introduction}

Because of the enduring legacy of Thomas Aquinas in the Catholic Church over the centuries, Thomism has provided the basis for Catholic educational theory and practice all over the world, including countries like Australio and India. Although he died at the relatively young age of 49, Thomas Aquinas left behind an astonishingly large body of work. However, only a very small part of it deals explicitly with education. While there are fleeting references to education scattered throughout his work, in the $11^{\text {th }}$ of the Questiones Disputate de Veritate (sometimes referred to as De Magistro) there is a major discussion on education. There are also references to education in Aquinas' commentary on Aristotle's Ethics. Even considering the fact that his monumental work, Summa Theologiae is a synthesis with an immense scope encompassing God, man and nature, some scholars believe that in as much as it deals with the way the human being should lead an ethical life and in 
as much as it examines the means for living such a life, the work is, in the broadest sense, an educational treatise. Reflecting on these aspects of the Summa, Donohue $(1967,118)$ adds, "After all, these are the fundamental concerns of education, and perhaps Dewey was thinking in similar fashion when he said that all philosophy is philosophy of education."

\section{Aquinas' Views on Education}

It is worth remembering that Aquinas used the term educatio not for intellectual development but for character formation. Having, like Aristolle, identified happiness as the ultimate goal of human life, Aquinas proposed that the goal of education should be the inculcation of virtue as a means of forming the character of the young so that they would lead a good life and attain happiness. This is why in his Commentary on the Sentences Aquinas defined educatio as "the advancement of the child to the state of specifically human excellence, that is to say, to the state of virtue" (Bk IV, dist. 26, q. 1, a.1).

Aquinas emphasised the substantial unity of body and soul, and the need to educate the whole person. He stressed the importance of parents in the education of their offspring and upheld their right against that of the state to decide on the type of education to be given to their children (Exposition of Aristolle's Ethics, 1, lect.1, no.4.) All this is firmly based on Aquinas' ideas on the nature of the human being. As Maritain (1943) notes, the Thomistic view of human nature included the Greek concept of the human being as a rational being whose highest faculty is the intellect; the Jewish concept of man as an individual endowed with free will and in relationship with God; and the Christian view of the person as "a sinful and wounded creature called to divine life and to the freedom of grace, whose supreme perfection consists of love" (7). Important principles follow from this view of the human being. These principles include:

- The existence of God as the creator and preserver of the universe

- The sinfulness of human beings

- The gift of Divine grace which enlightens the mind and strengthens the will so that individuals con know the truth and choose to live justly

- The supernafural destiny of all human beings

- The fundamental aim of Catholic education being identified as enabling the young person to acquire the knowledge and the strength of will necessary to attain his supernatural destiny (Elias, 1999, 96). 
In Aquinas' view, it is man's reasoning powers which distinguish him from the rest of creation. This being so, education should pay particular attention to the cultivation of the mind and for this the teacher should make use of sense-experiences because it is through our senses that we have an immediate contact with reality.

As a highly accomplished and effective teacher himsell, Aquinas reflected profoundly on a life devoted to teaching. He asks the question: "Does teaching belong to the active or contemplative life?" He answers: "Sometimes teaching pertains to the active life, sometimes to the contemplative: to the active when a man conceives within himself some truth such that by means of it he can be directed in exterior action; to the contemplative when a man conceives within some intelligible truth in consideration and love of which he delights (ST., II -II, q 181: Mclnerny, $1998,706)$. Thus, Aquinas found that the teacher's role is ideal for living a 'contemplative' as well as an 'active' life. This is based on the fwin objects of teaching: the pupil and the subject, as in "I teach Peter Mathematics". Because the teacher's role consists partly in expounding a particular subject - in the example above, Mathematics - he has the duty of understanding that subject at a deep level and of appreciating a) the beauty and truth that the subject represents and $b$ ) its relation to the welfare of human beings and to the glory of God. In this, the feaching role is ideal for a life of study and contemplation. However, teaching also requires a close interaction with the learner - in the case above, Peter - and nurturing his God-given abilities. This nurturing aspect of teaching also includes a) assisting in the intellectual development of the student so that he is able to understand the true nature of reality, and b) strengthening his will-power so that he is able to choose what is right and avoid what is wrong. Thus, the teacher's role has all the characteristics of the active life which, according to Aquinas, is a life of service to others as a means of serving God (ST., II -II, q.181 a.3, c; 182, a. 1, c.; De Veritate, q. 1), a4). As Aquinas points out, the active life consists chiefly in a human being's relations with his neighbour (ST., I - II, q.69 a.3c).

\section{Whitehead's Views on Education}

Those who are familiar with Alfred North Whitehead's ideas consider him one of the $20^{\text {th }}$ Century's most profound thinkers. While his ideas have attracted the admiration of philosophers, Whitehead's views regarding education are not as well known as they should be among teachers and teacher educators. However, when pre-service and in-service feachers are exposed to the educational ideas of Whitehead, they generally react with enthusiasm and are eager to explore practical ways for implementing these ideas in their own teaching. 
Whitehead defines education as "the acquisition of the art of the utilization of knowledge" (Whitehead, 1929, 6). This definition strikes teachers as an importont pointer to the close connection that exisis between theory and practice. Don Knuth's (1996) analysis of the etymology of the words 'theory' and 'practice' is relevant here. Knuth reminds us that both theory and practice are terms derived from the theatre: Practice (from the Greek 'Praktike') refers to a performance; and Theory, (from 'Theorema') refers to the viewing or study of a performance. Knuth goes on to remark, "You can see how the root words dichotomise the notions of theory and practice. Theoreticians sit in the audience and watch while practitioners are on stage actually doing something" (143). The terms, while dichotomous, are also closely linked in as much as the performer and the spectator need each other. In educational terms, of course, practice is the actual teaching and theory is the reflection on that feaching, and as such, they are both inextricably linked. No one can be an effective teacher without being able to reflect-i.e., 'theorise' - on his teaching practice. When writing of the end result of education, Whitehead suggests that it should result in a person "with something he knows well and something he can do well" and proceeds to point out that "This intimate union of practice and theory aids both" (Whitehead, 1929, 74).

Another aspect of Whitehead's definition is that he rejects the narrow view of education held by many people as the mere acquisition of information and suggests that it is closer in analogy to the assimilation of food: "It must never be forgotten", Whitehead reminds us, "that education is not a process of packing articles in a trunk. Such a simile is entirely inapplicable. It is, of course, a process completely of its own genus. Its nearest analogy is the assimilation of food by a living organism. And we all know how necessary to health is palatable food under suitable conditions" (Whitehead, 1929, 51). In this sense, Whitehead and Piaget had a similar view on learning as the absorption and assimilation of information and skills so that these become part and parcel of the learner. Whitehead rejects the concepfualisation of the mind as a kind of tool or instrument that needed sharpening, and he had no time for those who thought of the mind as a repository for what he termed 'inert' ideas, i.e., ideas which are received and stored in the mind without being examined or used, and which mean nothing to the individual and his life. As he considered the harm inflicted on the young by the dead hand of the conventional system of education and the consequences of wasted educational opportunities on the fate of nations, Whitehead was moved to righteous indignation: "When one considers in its length and in its breadth the importance of this question of the education of a nation's young, the broken lives, the defeated hopes, the national failures which result from the frivolous inertia with which it is treated, it is difficult to restrain within oneself a savage rage. In the conditions of modern life $[\ldots]$ the 
race which does not value trained intelligence is doomed. Not all your heroism, not all your social charm, not all your wit, not all your victories on land and sea, can move back the finger of fate" (Whitehead, 1929, 22).

What, then, is the subject matter of education? According to Whitehead, it is "life in all its manifestations" (Whitehead, 1929: 10). As Whitehead's contemporary, John Dewey would want to say, education is meant to illuminate life. Whitehead stipulated that education should provide the type of "knowledge which adds greally to character". This is knowledge so "handled as to transform every phase of immediate experience" (Whitehead, 1929, 49). Elsewhere he writes that education should guide the individual to develop his potentialities so that he is able to comprehend life more fully and develop the value system that would enable him to navigate the adventure of existence with all its possibilities" (Whitehead, 1929, 7). Values figure prominently in this philosopher's thinking on education. "The ultimate motive power, alike in science, in morality and in religion is the sense of value, the sense of importance. It takes the various forms of wonder, of curiosity, of reverence, of worship, of tumultuous desire for merging personality in something beyond itself" (Whitehead, 1929, 62-3). Hence for Whitehead the ultimate role that a well developed and comprehensive value system offers the individual is an intimation of the Transcendent. In this Whitehead echoes the ideas of Aquinas: that education should focus on providing the young person with the opportunities for gaining a deeper understanding of himself and the world, and for regulating his life according to clear ethical principles which enable him to live in harmony with all beings and to reach out to the Supreme Being.

A fundamental insight of Aquinas was on the need for the student to be fully engaged and active as a learner. He made this clear by drawing an analogy between the role of a physician and that of a teacher. Getting well, Aquinas pointed out, was something that the patient has to do for himself. By prescribing medicines and recommending certain behavioural changes, the physician seeks to enable the patient to use the recuperative powers of his own body to heal himself. The patient who is uncooperative and disengaged may have a much greater problem regaining his health. Similarly, the teacher can encourage the student, explain what he has to learn and ensure the provision of appropriate educational support, but it is the student who has to focus his mind and make the required effort to acquire the knowledge and skills which he needs (De. Ver., q. 11, a. lc). Extending the medical analogy, Aquinas emphasized the importance of humility as a prerequisite for all learning. Just as the patient who does not recognize a need for recovering his good health will not follow the advice of the physician, so too the student who does not recognize his ignorance and his need to learn will not have a receptive attitude to learning. 
The importance Aquinas placed on sense experience and active participation also led him to emphasize the value of manual work. Man is by nature an embodied spirit - material body and immaterial spirit forming one unique individual - and through his work, man is a co-creator with God the Creator of the universe. Hence Aquinas emphasized the union of reason (ratio) and hand (manus) as a true reflection of human nature, and this is why he thought of work as an activity being peculiar to the human being. "As is clear from the very structure of his body, man has a natural inclination to manual work. For this reason it is said in Job, 5, 7: 'Man was born to labour and the bird was born to fly' (ST., I. II, q. 95, a. 1, c). Donohue (1967) notes how through human work, an idea is embodied in matter. Thus, out of some timber, the cabinetmaker fashions a table, or out of a few acres of land the farmer creates a house and garden.

Following on from this idea, Aquinas believed that happiness, which is the purpose of life and of education, could not be attained without putting oneself at the service of other human beings, and, consequently, of God. Hence, the educator, as one deeply interested in the happiness of his students, has the responsibility of training them in the service of the community. In the words of Aquinas, "A thing is perfect in so far as it achieves the oppropriate end which is its ultimate perfection. But it is love which unites us with God, our ultimate end $[. .$.$] and so the perfection of a$ Christian life is determined principally by love (ST., II-Il, q.184, a. I, c).

In his emphasis on the importance of sense experience and the active engagement of the student in learning, Whitehead was in agreement with Aquinas. Whitehead condemned the bookish noture of much of today's education and, as we have noted earlier, rejected the conventional dichotomy between theory and practice: "The antithesis between a technical and a liberal education is fallacious. There can be no adequate technical education which is not liberal, and no liberal education which is not technical: that is, no education which does not impart both technique and intellectual vision" (Whitehead, 1929, 67). As he wrote in Science and the Modern World, "The general training should aim at our concrete apprehensions and should satisfy the itch of youth to be doing something. There should be some analysis even here but only just enough to illustrate the ways of thinking in diverse situations" $(1927,247)$. Together with the injunction to be practical is Whitehead's advice to teachers not to cover too many subjects but to teach thoroughly the material which they have carefully selected for the child. What is important is not the number of ideas but the way the child is encouraged to make those ideas his very own and apply them to the situations in his own life. "From the very beginning of his education the child should experience the joy of discovery. The discovery which he has to make is that general ideas give an understanding of the stream of events which pours through his life. ... Pedants sneer at an education which is 
useful. But if education is not useful, what is it? Is it a talent to be hidden in a napkin? Of course, education should be useful whatever your aim in life" (Whitehead, $1929,1)$.

What does learning involve? Basically it is the internalising of knowledge which is then used by the individual for understanding and dealing with the self and the world. Whitehead advocated the integralion of knowledge for this purpose. He did not believe in offering English, Mathematics, Science, History, etc. as stand-alone, compartmentalised subjects. If this was done, he said, the curriculum would become "a rapid table of contents which a deity might run over in his mind while he was thinking of creating a world and has not yet determined how to put it together" (Whitehead, 1929:4) Elsewhere he cautions: "You many not divide the seamless coat of learning" (Whitehead, 1929, 18).

In Whitehead's conceptualisation, learning is a process which takes place in a temporal framework and which involves the growth and development of both the individual and the subject matter. Whitehead identified three stages in this growth and called them the stage of romance, the stage of precision and the stage of generalisation. Writing of this aspect of Whitehead's ideas, Robert Brumbaugh $(1982,4)$ notes, "If learning is to be an integral part of a student's existence and growth, it must follow the three-stage pattern in which growth and concrescence take place."

Every learning experience begins with the stage of romance: a fascination, an emotional involvement and a deep engagement with the subject matter, or, in the words of Malcolm Evans (1997), "an intriguing, romantic connection with learning". The learner is even subconsciously attracted to the subject matter and is aware that it is going to satisfy some important need of the moment. There is a feeling of immediacy and an intuitive grasp of the multiple relationships which the current subject matter shares with other areas of interest to the learner. Whitehead's concept of the stage of romance imposes on the educator the obligation to make learning as interesting, engaging and relevant as possible to the young learner.

The stage of precision refers to the 'exactness of formulation' (Whitehead, 1929, 18). At this stage, there is a focus on accuracy in the way the subject matter is conceptualised and sfudied. The stage of precision calls for clear analyses, coolheaded calculations and accurate conclusions. At this stage the learner studies the subject matter at a level of depth commensurate with his intellectual development, together with the detachment of the mathematician and the scientist, whereas at the earlier stage of romance the learner viewed the same subject matter with the mesmerised eyes of a poet: In the words of Keats, "Like a watcher of the skies/ when 
a new planet swims into his ken". In some ways the stage of precision is familiar territory because most of the fraditional curriculum is generally faught with accuracy in mind. However, no matter how important this stage is in the learning process, without the stage of romance which precedes it and the stage of generalisation which follows it, for many students the effort to learn during the stage of precision can become an onerous and even stultifying chore. As Whitehead warns us, an educational system that focused exclusively on the ideal of precision may tend to become so much oriented towards reverse the verses of Genesis: "In the Garden of Eden Adam saw the animals before he named them: in the traditional system the children named the animals before they saw them" (Whitehead, 1927, 285).

The stage of generalisation takes what has been learnt and, ofter examining the implications and ramifications of the ideas and skills which have been mastered, applies them to some sphere of the individual's and/or the community's life. This is the sfage where education bears fruit in the betterment of the individual and the community. At this stage the student is able to glimpse the philosophical import of the new knowledge and skills and this prepares the ground for the next spiral of growth through the three stages of romance, precision and generalisation. This is a cycle that is repeated right through the life of the individual and this is the reason that Whitehead, like Dewey, conceptualised education as a life-long process.

Whitehead considered teaching to be an art "The function of art is to turn the abstract into the concrete and the concrete into the abstract. It elicits the abstract form from the concrete marble. Education in every branch of study and every lecture is an art. The emphasis may be more on the abstract or more on the concrete. But always there remains the inescapable problem of the marriage of form to matter" (Whitehead, 1961, 151).

There is no denying the conclusion that Alfred North Whitehead presents the modern educator with challenging and inspiring ideas. He was able to drill down to the absolute core of what thousands of authors spanning 25 centuries have tried to convey through countless words regarding the principles and methods of teaching, in the following simple sentence: "The first thing that a teacher has to do when he enters the classroom is to make his class glad to see him" (Whitehead, 1948, 126).

\section{Comparing the Views of Aquinas and Whitehead on Education}

Scholars who have critically examined the views of Aquinas and Whitehead on education have noted both points of similarity and points of difference in the 
educational views of these philosophers. According to Hill (1979) both the philosophers agree that "there is a God without whom the universe would be unintelligible; that human agency is our analogue for conceiving of the deity; and that divine agency is in the end an agency of love" (249). Ford (1979) points out that while the philosophy of St. Thomas has many fine qualities, it can no longer serve one of its primary purposes, namely, the reconciling of Christian faith with science. Ford makes the bold claim, "Were Thomas alive today there are several reasons to think his philosophy would more closely resemble Whitehead's" (237). Basically, Ford bases his assertion on the following: (a) that both philosophies are "hospitable to Christian concerns", and (b) that they are both creationist philosophies. The divergence is to be found in their views on creation: Thomas has a "monistic transcendent" creationist version" in which God who is Himself uncreated "creates a world incapable of creation." Whitehead, on the other hand, has a "pluralistic immanent" take on creation in which "each actuality creates itself out of others, and God is its chief exemplification". Ford goes on to say that in Whitehead's version, the dynamism of evolution can be seen "as the most natural way in which God could persuade the world to create itself" $(237)$. Hill $(1979,249)$ notes that in Whitehead's view, "God's love of the world, though benign, is not free nor is it creative. Further, its intent is God's self-fulfilment. God everlastingly stands in need of the world, as means to his own growth in value-experience."

While the different world-views of these philosophers have implications for educational philosophy, on most fundamentals they are in accord: Both of them regard education as an inalienable right of the individual and as being essential for the well-being and progress of society. Both of them advocate $a$ balance between the theoretical and the practical in the education of the young; both of them emphasise the use of the senses in learning; both of them point to the need for learning to be relevant and useful in providing the learner with a clear understanding of his identity and his relation with sociely and the world; and finally, both these philosophers have a high regard for the rights of the learner and for the crucial role of the educator as a caring professional in whose hands rest the future of the nations.

\section{Reference}

01. Brumbaugh, R. S., Whitehead, Process Philosophy and Education. Albany: Stale University of New York Press, 1982.

02. Donohue, J. W., The Scholaslic: Aquinas. In P. Nash, A.M. Kazamias, \& H. J. Perkinson, The educated man: Studies in the history of educational thought (pp.114-139). New Your: John Wiley \& Sons, 1967.

03. Elias, J. L., "Whatever happened to Catholic philosophy of educolion?" Religious Educotion, 94 (1) (1999), 92+110. 
04. Evans, M. D., "Process philosophy of education: A personal journey." Process Popers: An Occasional Publication of the Association for Process: Philosophy of Education 4 (December 1999), 14-28.

05. Ford, L. S., "Thomas Aquinas and contemporary philosophical options." Listening 14, 3 (1979), 237-248.

06. Hill, W. J., "Two Gods of love: Aquinos and Whitehead." Listening, 14, 3, (1979), 249-264.

07. Kenny, A. (Ed.), Aquinas: A collection of critical essays. London: Macmillan. 1969.

08. Knulh, D. E., Selected popers on computer science. Cambridge, UK: Cambridge University. Press, 1996.

09. Maritain, J., Education at the crossroads. New Haven: Yale University Press, 1943.

10. Mclnerney, R. (Editor and Iranslator), Thomas Aquinas: Selecled writings. London: Penguin Books, 1998.

11. Redden, J. D. \& Ryan, F. A., A Cotholic philosophy of education. Milwaukee: The Bruce Publishing Company, 1942.

12. Whitehead, Alfred North, Science and the modern world. New York: Macmillan, 1927.

13. Whitehead, Alfred Norh, The Aims of Educalion and Other Essays. New York: Macmillan, 1929.

14. Whitehead, Allred North, Adventures of Ideas. New York: Macmillan, 1933.

15. Whitehead, Altred North, Modes of thought. New York: Macmillon, 1938. 